\title{
Evaluation of Turmeric (curcuma longa linn.) and its Extracts from Indian Market
}

\author{
Kilambi Pundarikakshudu*, Priya A Shah, Pooja D Shah and Anu V Patel \\ Department of Pharmacognosy, LJ Institute of Pharmacy, India
}

Submission: May 1, 2018; Published: August 17, 2018

*Corresponding author: Pundarikakshudu K, Department of Pharmacognosy, L J Institute of Pharmacy, Between Sarkhej Circle and Kataria Motors, SG Road, Ahmedabad- 382210, India, Tel: +91-79-29296421; +91 7600568631; Email: P_kilambi@yahoo.com

\begin{abstract}
Turmeric, (Curcuma longa), has been used for its coloring, flavoring, and digestive properties. It has antibacterial, anti-tumour, antiinflammatory, anti-diabetic and anti-oxidant activities. It is also highly valued as a cosmetic. The main chemical constituents responsible for these activities are phenolic curcuminoids. With rapid advances in Nutraceuticals, the herbal drug industries are increasingly resorting to employing standardized herbal extracts in the formulations. But the extracts supplied by different manufacturers were sometimes found to be completely lacking in quality. Hence, it was decided to prepare the extracts and oleoresins of turmeric and compare them with the marketed samples. Turmeric powder was purchased from local market and water extract and alcoholic extract (turmeric oleo resin) were prepared in our laboratory. Different samples of turmeric powder, turmeric oleoresin and water extract prepared in our laboratory were analyzed by two different spectrometric methods; one by direct measurement of the colour at $425 \mathrm{~nm}$ and the other by development of color with boric acid and measuring the color at $540 \mathrm{~nm}$. We found colorimetric method more suitable as it is very specific to curcumins. Marked differences in curcumin content (ranging from 1.0 to $45 \%$ ) were noted in different market samples. These may be due to various factors such as improper extraction method, wrong choice of solvents and excessive addition of diluents etc.
\end{abstract}

Keywords: Turmeric Powder; Turmeric extracts; Spectrophotometric method; Boric acid method

\section{Mini Review}

Turmeric (Curcuma longa Linn.) is a dietary food item in the oriental cuisines and is claimed to have a number of medicinal properties such as anti-inflammatory, anti-oxidant and anticancer activities. The color and the medicinal activities of turmeric are due to a phenolic compounds collectively known as curcumins [1].

Curcumin is proving to be a potential drug molecule due to its multifarious activities and its freedom from toxicity [2,3]. Number of studies on designing of various formulations of curcumin are underway [4]. These formulations employ either pure curcumins or standardized extracts. The curcumins in the extracts and powders are analyzed employing different methods such as HPLC, Spectrophotometric [5] and HPTLC [6,7] methods. The present study was undertaken to evaluate different powder samples and extracts of turmeric available in the market along with the extracts prepared in our laboratory by employing spectrophotometric methods.

\section{Material and Methods}

Pure curcumin reference standard was gift from Dishman Pharmaceutical Ltd, Ahmedabad. Turmeric powder was procured from local market and various samples of turmeric oleoresins were procured from different commercial suppliers. Turmeric oleoresin was prepared by soxhlet extraction using ethanol as solvent and water extract by distilled water. All the chemicals used for analysis were of analytical grade. Spectrophotometric measurements were done on a Shimadzu double beam spectrophotometer model no 1601 using pair of matched quartz cell. All the experiments were carried out in triplicates.

\section{Preparation of standard curve of curcumin by spectro- photometric method}

Stock solution of curcumin $(100 \mu \mathrm{g} / \mathrm{mL})$ was prepared by dissolving $10 \mathrm{mg}$ in $100 \mathrm{~mL}$ ethanol. Aliquots of $0.2,0.4,0.6$, 0.8 , and $1.0 \mathrm{~mL}$ were transferred in $10 \mathrm{mLvolumetric} \mathrm{flasks} \mathrm{and}$ volume was adjusted with ethanol to produce the standard solutions of 2, 4, 6, 8 and $10 \mu \mathrm{g} / \mathrm{mLconcentrations.} \mathrm{Absorbance}$ of all these solutions was taken at $425 \mathrm{~nm}$ using ethanol blank.

\section{Preparation of standard curve of curcumin by colori- metric method (Boric acid method)}

Aliquots of $0.25,0.5,1.0,2.0,3.0,4.0$ and $5.0 \mathrm{~mL}$ above stock solution was transferred in $10 \mathrm{~mL}$ volumetric flask and evaporated to dryness in water bath. To each of these, added $1 \mathrm{mLof} 6 \%$ boric acid solution and the volume adjusted to the mark with glacial acetic acid to produce 2.5 , 5.0, 10.0, 20.0, 30.0, 
40.0 and $50.0 \mu \mathrm{g} / \mathrm{mL}$ of solutions. Blank was prepared as above omitting the aliquots of curcumin stock solution, Absorbance of each of these solutions were measured at $540 \mathrm{~nm}$ against blank.

\section{Extraction and analysis of turmeric powder, extract / oleoresin, and curcumin}

One gram of each sample was extracted completely in ethanol and filtered; volume was adjusted to $100 \mathrm{~mL}$ with ethanol. After suitable dilution of this solution with ethanol, the content of curcumin was analyzed by the methods described above.

\section{Results and Discussion}

Curcumins were found to obey Beer's law between concentration ranges of $2-10 \mu \mathrm{g} / \mathrm{mL}$ in spectrophotometric method and 2.5-50 $\mu \mathrm{g} / \mathrm{mL}$ in boric acid method. Powder samples of turmeric showed curcumins ranging from 4. 0-4.5 \% w/w. These observations are consistent with the reported literature. Water extractive values were found to be $20.0 \% \mathrm{w} / \mathrm{w}$. But this extract was found to be very poor in curcumin content. It had as low as $0.4 \%$. w/w of curcumin. This is expected as curcumins are not known to be soluble in distilled water.

Table 1: Curcumin content $(\% \mathrm{w} / \mathrm{w})$ in Turmeric and its Extracts/ Oleoresins.

\begin{tabular}{|c|c|c|}
\hline \multirow{2}{*}{ Sample of Turmeric } & \multicolumn{2}{|c|}{$\begin{array}{c}\text { \% w/w of Curcumin (Average of three } \\
\text { readings) }\end{array}$} \\
\cline { 2 - 3 } & Boric acid method & $\begin{array}{c}\text { Spectrophotometry } \\
\text { method }\end{array}$ \\
\hline Powder-1 & 4.18 & 4.5 \\
\hline Powder-2 & 3.97 & 4.3 \\
\hline Water extract & 0.375 & 0.42 \\
\hline Alcohol extract & 35 & 45 \\
\hline $\begin{array}{c}\text { Oleoresin- sample-1 } \\
\text { (Paste) }\end{array}$ & 45 & - \\
\hline $\begin{array}{c}\text { Oleoresin- sample-2 } \\
\text { (Paste) }\end{array}$ & 42 & - \\
\hline $\begin{array}{c}\text { Oleoresin- sample-3 } \\
\text { (Paste) }\end{array}$ & 25.4 & - \\
\hline $\begin{array}{c}\text { Oleoresin- sample-4 } \\
\text { (Paste) }\end{array}$ & 3.05 & - \\
\hline $\begin{array}{c}\text { Oleoresin- sample-5 } \\
\text { (Paste) }\end{array}$ & 1.12 & - \\
\hline $\begin{array}{c}\text { Oleoresin- sample-6 } \\
\text { (Dry powder) }\end{array}$ & 22 & - \\
\hline $\begin{array}{c}\text { Oleoresin- sample-7 } \\
\text { (Dry powder) }\end{array}$ & 4.5 & - \\
\hline $\begin{array}{c}\text { Oleoresin- sample-8 } \\
\text { (Dry powder) }\end{array}$ & 7 & \\
\hline
\end{tabular}

Alcoholic extraction yielded $12.0 \% \mathrm{w} / \mathrm{w}$ extract which is deep yellow, resinous and oily in nature. This oleoresin extract was found to be very rich in curcumins (35-45\% w/w). Turmeric extracts from market were also analyzed by the two methods. They differed in their physical appearance and color. Some of them were claimed to contain as high as $25 \%$ curcumins by the suppliers. However, it was noted that these samples have very low amounts of curcumins. The data of the analyses are presented in Table 1.

Curcumins available in the market were found to be $79 \%$ to $95 \%$ pure. All these samples and the reference curcumins exhibited three major spots on TLC when developed in chloroform: methanol (25: 1). It is evident from the data in table that direct spectrophotometric method gave slightly higher results as compared to the results with boric acid method. Boric acid method is specific for curcumins whereas some other closely shaded colors might also have added to the yellow color in ethanol. This is possible as no purification step is involved in the analysis and ethanol extract was directly taken for analysis. Hence, we opine that boric acid method should be preferred to spectrophotometric method.

The reason for varying amounts of curcumins noted especially in the extracts may be improper selection of the solvent. It is possible that water is employed for the extraction in stead of the organic solvents like ethanol/acetone/ethyl acetate. Many manufactures insist on a free flowing powder form of the herbal extracts for convenience of formulation. As a result, in majority of cases, diluents like lactose, dextro-mannose, dicalcium phosphate etc are added to the extracts thus ultimately resulting in dilution of the active ingredients.

Thus, our studies highlight the discrepancies in the quality of extracts which are, of late, widely employed by a number of herbal drug manufacturers. This study also further emphasizes the need to evolve uniform S O Ps for preparation and evaluation of herbal extracts.

\section{References}

1. Cooper TH, Clark G, Guzinski J (1994) Teas, spices and herbs. In: Food Phytochemicals, ed. Ho, CT, Washington, DC: American Chemical Society 1: 231 - 236.

2. Allen PC, Danforth HD, Augustine PC (1998) Dietary modulation of avian coccidiosis. Int J Parasitol 28(7): 1131-1140.

3. Mazumder A, Wang S, Neamati N, Nicklaus M, Sunder S et al. (1996) Antiretroviral agents as inhibitors of both human immunodeficiency virus type 1 integrase and protease. J Med Chem 39(13): 2472 - 2481.

4. Ammon HPT, Wahl MA (1991) Pharmacology of Curcuma longa. Planta Med 57(1): 1-7.

5. Chauhan SK, Singh BD, Agrawala S (1999) Estimation of curcuminoids in Curcuma longa by HPLC and spectrophotometric methods. Indian J Pharm Sci 61(1): 58-60.

6. Dwivedi AK, Raman M, Seth RK, Sarin JP (1993) Combined thin-layer chromatography-densitometry for the quantitation of curcumin in pharmaceutica L dosage forms and in serum. Indian J Pharm Sci 55(5): 174-177.

7. Pundarikakshudu K, Dave HN (2010) Simultaneous Determination of curcumin and berberine in their pure form and from the combined extracts of Curcuma longa and Berberis aristata. Int J Appl Sci and Engi 8(1): $19-26$ 
This work is licensed under Creative Commons Attribution 4.0 License

DOI: 10.19080/JCMAH.2018.06.555700

\section{Your next submission with Juniper Publishers will reach you the below assets}

- Quality Editorial service

- Swift Peer Review

- Reprints availability

- E-prints Service

- Manuscript Podcast for convenient understanding

- Global attainment for your research

- Manuscript accessibility in different formats

(Pdf, E-pub, Full Text, Audio)

- Unceasing customer service

Track the below URL for one-step submission https://juniperpublishers.com/online-submission.php 